\title{
Entrepreneurship and Strategic Management: A Critical Analysis on These Paradigms' Relationship
}

\author{
Gyanendra Bikram Shah, MPhil
}

\begin{abstract}
The purpose of this study is to provide a better understanding of the arguments concerning the various views provided by different academics in the fields of entrepreneurship and strategic management and then to find a position in which practice is generally agreed on by the divisions. The researcher examined the fundamental theories of the two paradigms of entrepreneurship and strategic management and also examined existing literature submitted by scholars in the fields who tried to look at the intersection of the two paradigms. This post, however, aims to highlight the need to see the two disciplines as being similar from various parental perspectives. Literature on each of the paradigms was checked to provide a better understanding of them. The researcher was able to consider such intersecting variables, such as culture, which was seldom stressed as a factor influencing the opportunity-seeking conduct of an entrepreneur and competitive advantage-seeking activities to create wealth and ensure the economic development and survival of an organization.
\end{abstract}

Keywords: Entrepreneurship, opportunities, entrepreneur, strategic management, competitive advantage, create wealth and economic development.

\section{Introduction}

Many management scholars have expressed many views about how best to cope with these challenges and remain sustainable within the competitive landscape due to the rising environmental dynamics and intensifying global competition between small and large companies. Organizations regardless of their years of existence in the business domain are compelled to build more entrepreneurial strategies for survival (Hitt, Ireland, \& Hoskisson, 2001; Meyer, Neck, and Meeks, 2002). According Hitt, Ireland, Camp, and Sexton, (2002) these entrepreneurial strategies are seen to be closely related for firms' performance in the sense that both aim at the identification of opportunities and develop them to have competitive advantage over other competitors in the business environment. It is on this assumption that the areas of entrepreneurship and strategic management seem to converge, giving rise to the idea of Strategic Entrepreneurship. Bettis and Hitt (1995), Hitt et al (2001), Ireland et al (2001) posited that the concept of entrepreneurial strategy is so significant to both new ventures and established firms as it actually determines firm's success in the competitive landscape.

While the above scholars look at the intersection and advancement of the two paradigms of entrepreneurship and strategic management, however, the researcher is keen to understand, taking into account their theoretical origins and divergence, the reality of the marriage between entrepreneurship and strategic management and to further indicate which side of the divisions should be general or universally accepted. 


\section{Theoretical Foundation of Entrepreneurship}

Different academics have postulated a lot of entrepreneurship theories to give the paradigm of entrepreneurship a simple sense. All the theories put forward appear to have their root from the fields of economics, psychology, sociology, anthropology, and management (Simpeh, 2011). The following theories were identified as a field of research for the birth of entrepreneurship;
A) Theory of Economic Entrepreneurship
(b) Theory of Psychological Entrepreneurship
C) Theory of Sociological Entrepreneurship
D) Theory of Anthropological Entrepreneurship
E) Entrepreneurship Theory Opportunity-Based
F) Theory of Resource-Based Entrepreneurship
G) Theory of Human Capital Entrepreneurship

\section{Theory of Economic Entrepreneurship:}

The economic entrepreneurship theory of the classical, neoclassical and Austrian business mechanism (AMP) has deep roots. These theories address the economic conditions that fuel entrepreneurial behavior. The neoclassical theory, born out of criticism of classical theory, argued that economic phenomena should be confined to instances of pure exchange, reflect an ideal ratio, and transpire in an economic system that is fundamentally closed. The system comprises of exchange participants, exchange occurrences and its relevant impacts on other market actors (Murphy, Liao \& Welsch, 2006). Another entrepreneurship as a driver of market-based structures was described by Schumpeter (1934). In other words, it was an important feature of an enterprise to create something new that resulted in processes that served as impulses for the movement of the consumer economy. However, this did not mean that changes should not take place, but rather that as soon as the changes were established, all parties concerned could adapt to the new situation. In other words, development was seen as a disruption to the circular flow and attributed to entrepreneurs who, as innovators, played a key role in the implementation of innovations in the form of new products, markets or methods.

\section{Theory of Psychological Entrepreneurship:}

Landstrom (1998) claimed that the standard of evaluation is at the person level in psychological theories. Psychological entrepreneurship theories emphasize the personal characteristics which characterize entrepreneurs. There are creativity, risk-taking, and respect for uncertainty. Below this, we have 'Personal Characteristics and the Locus of Influence.' The theorists of traits believe that the inborn characteristics of a person exist that render him an entrepreneur automatically. The locus of control is a term that Juliana Rotter introduced in the 1950s. Rotter (1966) refers to the locus of influence as the understanding of a person about the key underlying causes of events in his or her life. It is about the idea that the consequences of our actions depend on what we do or on circumstances outside our personal control. Here, the success of an entrepreneur is believed to come from his or her own capacity and from outside motivation as well. The "Need for Achievement theory" is another sub-theory of psychological entrepreneurship theory. McClelland (1961) thinks that it is important for human beings to succeed, accomplish, excel, or achieve. What inspires entrepreneurs is this.

\section{Theory of Sociological Entrepreneurship:}

The social context is based on this ideology. That is to suggest that culture is the analytical area (Landstrom, 1998). Four (4) social context defined as linked to entrepreneurial opportunities; context of social networks, context of life course level, context of ethnic identity context of population ecology context of Reynoldss (1991). The social network is all about building a social union that fosters trust and 
faith in opportunism, i.e. entrepreneurs are not expected to take undue advantage of people to succeed. Taking a close look at the characteristics and life conditions of people who want to become entrepreneurs is the context of the life course process. The sense of ethnic identity examines the social past of the wouldbe entrepreneur. Finally, population ecology, which focuses on environmental (external) variables that can impact the viability of new ventures.

\section{Theory of Anthropological Entrepreneurship:}

The theory of anthropology claims that social and cultural backgrounds must be properly taken into account in order for someone to start a business effectively (venture). The key emphasis here is on culture that leads to an entrepreneurial attitude such as innovation that further leads to the growth of Simpeh businesses (business establishment) (2011). Anthropology itself, as proposed by Simpeh, is the study of the origins, development, customs and beliefs of a culture. Baskerville (2003) suggests that the cultural environment is capable of generating differences in attitudes among entrepreneurs.

\section{Entrepreneurship Theory of Opportunity -Based:}

Names such as Peter Drucker and Howard Stevenson anchor the opportunity-based entrepreneurship theory. In his opinion, Drucker (1985) argued that entrepreneurs do not cause change, as the Schumpeterian School of Thought postulates, but that entrepreneurs take advantage of opportunities that produce change. Drucker sees entrepreneurs as people who pursue advancement, adapt to it, and use it as an opportunity. It is clear that all of Drucker's submissions point to the fact that entrepreneurs are more concerned with the possibilities produced by change than with the problems. In Drucker's opportunity-based system, Stevenson (1990) went on to suggest that the hallmark of entrepreneurial management is the pursuit of opportunity without resorting to resources currently owned by the entrepreneur.

\section{Theory of Resource-Based Entrepreneurship:}

This theory argues that capital access is a critical indicator of opportunity-based entrepreneurship and development in new projects. More focus was placed on financial, human and social capital in this theory. Therefore, they reflect three forms of theories within resource-based entrepreneurship. The theory of financial capital (liquidity) indicates that individuals with financial capital are more able to acquire resources to effectively take advantage of entrepreneurial opportunities and set up a company to do so (Clausen, 2006), cited in Simpeh (2011). This argument by Clausen has come under attack by other scholars such as (Hurst and Lusardi, 2004; Davidson, \& Honing, 2003) who believe that without much money, most founders start fresh business. The theory of social capital or social network assumes that the social relation of the person is important for transforming the opportunity that is recognized into a start-up company (Shane \& Eckhardt, 2003).

\section{Theory of Human Capital Entrepreneurship:}

This theory takes two key factors into account: education and experience. Knowledge acquired and experience gained throughout the years are assets that are heterogeneously distributed through individuals and are therefore important for identifying variations in the identification and use of possibilities' (Anderson \& Miller, 2003; Chandler \& Hanks, 1998; Shane \& Venkataraman, 2000).

\section{Theoretical Paradigm of Strategic Management}

Strategic management ideas mainly stem from the process approach, the contingency approach and the information technology approach. In management literature, the main strategic management theories observed are;

A) Profit Maximization and philosophy focused on competition 
(b) Theory of Resource based,

C) Theory based on survival,

D) Theory of Contingency

E) Theory Based on Human Capital.

\section{Profit Maximization and philosophy focused on competition:}

This theory is based on the belief that the primary aim of a corporation is to maximize long-term profit and also ensure a sustainable competitive advantage in the external market environment over its rivals.

\section{Theory of Resource Based:}

This theory stems from the assumption that the essence of an organization's competitive advantage over its rivals is the unique resources and abilities it possesses and not inherently its position in the external environment or simply the study of opportunities and risks when conducting business in the external environment.

\section{Theory based on Survival:}

Survival-based theorists claim that in order to thrive, companies need to continuously adjust to their competitive climate.

\section{Theory of Contingency:}

This theory holds the view that every specific and optimal approach/procedure does not control organizations. It means that companies should develop unique management strategies that fit the issue or situation facing the organization at the moment, so there can be no sacrosanct approach.

\section{Theory Based on Human Capital:}

The human resource-based theory stressed the importance of the human capital element in the formulation and growth of the strategy and overall output of the organization. This theory holds the view that the root of the company's competitive advantage lies in its highly skilled and active staff that cannot be easily replicated by other competitors in the market or business climate.

\section{Theoretical fields of entrepreneurship and strategic management parallel}

A critical perspective on the fundamental theories of entrepreneurship and strategic management, as reflected above, shows that both fields of study have distinct origins, but with certain elements of similarity that makes their union almost non-negotiable. While entrepreneurship is embedded in fields such as economics, psychology, sociology, anthropology and management (Simpeh, 2011), strategic management theories are focused on the approach to processes, contingency approach and approach to information technology (Ologbo, Oluwatosin, \& Kwakye, 2012). However, even with this, the two paradigms of entrepreneurship and strategic management are evidently related by some theories. For example, in entrepreneurship, we have a resource-based philosophy that emphasizes the importance of being able to access capital to explore entrepreneurial opportunities and set up a company to do so (Clausen, 2006).

Although strategic management's resource-based theory holds the view that its unique resources and expertise are the foundation of an organization's competitive advantage over its business rivals. In order to explore entrepreneurial possibilities and to attain competitive advantage, both theories stressed the importance of capital in the business climate. In addition, another intersecting theory of entrepreneurship and strategic management is the human resource-based theory. In entrepreneurship, the theory looks at 
two key factors: education and practice. This means that the knowledge and experience accumulated over a period of time are important to finding inconsistencies and exploiting opportunities (Anderson and Miller, 2003; Chandler and Hanks, 1998). This underlines the fact that both seem to understand the fact that education and expertise are important to the exploitation of wealth creation opportunities and to the competitive advantage of the company in the business landscape. In addition, the economic viewpoint of the theory of entrepreneurship coincides with the theory of strategic management of benefit maximizing.

\section{Paradigm Entrepreneurship}

There are a wide range of definitions of the concept of entrepreneurship. Depending on the situation and the perspective examined by a scholar, it is a complex term that provides various meanings. In the 1700 s, the concept was first developed and the notion has since evolved. Furthermore, the Institute of Company Secretaries of India, on the basis of its own specific way, various economists and philosophers referred differently to the concept of entrepreneurship (2012). The principles of entrepreneurship come from a number of fields of study, including classical and neoclassical economics, psychology, sociology, and management. As a result of the multidisciplinary nature of the word, it would be hard to come up with a widely acclaimed definition. For example, entrepreneurship was linked with a national culture by the likes of Shane (1994), McGrath, MacMillan and Schein berg (1992), and other scholars such as Zimmerer and Scarborugh (2005) looked at it from an entrepreneurial environment perspective. However, whatever idea is presented by a researcher should be captured by both the individual elements and the environmental possibilities present. Entrepreneurship can therefore be described as all attempts to make money, gain profit and generate wealth while presenting features such as risk-taking, leadership management and innovation (Institute of Company Secretaries of India, 2012). Several academics have seen entrepreneurship as one of the driving forces of modern economics today (brock \& Evans, 1989; Carree \& Thurik, 2000). It takes entrepreneurial ingenuity and innovation for the economy of any nation to move forward. Entrepreneurs produce and take advantage of developments, are imaginative and have the ability to accumulate capital. Entrepreneurship goes beyond the development of new projects, but may also take place in existing or developed companies where renovation and creativity are essential objectives (Stevenson \& Jarillo, 1990; Sharma and Chrisman, 1999). Consciously exploiting and finding possibilities by product creation or looking for new markets or both are some of the fields in which entrepreneurs concentrate on their attempt to build value Lumpkin, Shrader, \& Hills, !998; Shane \& Venkataraman, 2000). In the business world, the whole idea is to get an edge over and above competitors in order to achieve competitive advantage. In comparison to other scholars' positions on the philosophy of entrepreneurship, Schumpeter (1934) correlated entrepreneurship with creativity. The notion of creative destruction by entrepreneurs came to him as well. Entrepreneurship in the sense of social and financial change. The Concise Oxford Dictionary (Allen, 1990) defines an entrepreneur as 'a person who, with a chance of benefit or loss, undertakes an enterprise or business; a contractor acting as an intermediary; the entity taking effective control of a commercial enterprise.

\section{Paradigm Strategic Management}

The underlying basis of the philosophy of strategic management is based on the view that strategy produces equilibrium in its external environment between the internal strengths and weaknesses of the organization (SWOT) on the one hand and its opportunities and challenges on the other (Andrews, 1987). According to Furrer, Thomas and Goussev-Skaic strategic management as a field of study can be traced to the 1960s (2007). At the Pittburgh Conference, strategic management was first suggested in the early 1980s to describe a modern corporate strategy model. The definition of business strategy was then rewritten as 'strategic management' Rama Chandran et al (2006) suggests that the emphasis of strategic management is the advancement of competitive advantage with the goal of wealth creation. Significant sources of 
sustainable competitive advantage (Prahalad \& Hamel, 1990) and Porter, 1985) are seen to be the acquisition of important, rare and non-imitable and non-substitutable resources with a favorable market position. This is the cornerstone on which the philosophy of resource-based strategic management is anchored.

\section{Reconciling entrepreneurship and strategic management paradigms}

Entrepreneurship and strategic management tend to emanate from multiple areas that are theoretical yet interrelated. Output is seen by most researchers in both fields as a significant dependent variable. At the heart of both is the discovery and utilization of possibilities to build wealth. By finding opportunities in the market environment and further creating a competitive advantage to take advantage of the identified opportunities, Company generates value (Hittet al, 2001; Ireland et al, 2001). "As cited by Kraus \& Kauranen (2009), Venkataraman and Sarasvathy (2001) used a figurative term that takes cognizance of Shakespeare's Romeo and Juliet, saying that "strategic management research without an entrepreneurial perspective is like the balcony without Romeo, and market research without a strategic perspective such as Romeo without a balcony. However, six domains where entrepreneurship and strategic management converge (Covin \& Miles, 1999; Hitt \& Ireland, 2000; Ireland et al, 2001) have been identified; creativity, network, internationalization, organizational learning, top management teams and governance and growth.

An entrepreneurial culture seeks to alter the relationship between a company and its environment, while studying culture related to strategic management seeks to understand this relationship. Cultural entrepreneurs are resourceful, visionary, extracting income from culturally rooted information structures (Kavousy, Shahhocseini, Kiasi and Ardahaey, 2010). Entrepreneurial behavior is thought to be unpredictable and strongly affected by cultural characteristics (Hofstede, 1980, 2001) and entrepreneurship (Hofstede, 1980, 2001). (McGrath, MacMilan \& Scheinberg, 1992).

The ability of an organization to deliver results depends on the approach it adopts from a strategic point of view. In turn, an enterprise's strategies rely largely on the organization's climate and culture. Different cultures give rise to specific strategies in various types of industries. Yabrough, Morgan and Vorhies (2011) assume that the connection between culture and strategy affects an organization's outcome and efficiency, i.e. the strategic thinker is affected by the organizational culture and the developed strategy affects an organization's performance. Organizational culture has a high performance effect and strong performance affects culture rather than poor ones. Indeed, as academic fields of research, entrepreneurship and strategic management principles both work in the external world, local or international, with cultural variations, thus describing the degree to which these cultures affect the exploitation and discovery of opportunities in the business landscape and the strategic thinker's competitive advantage seeking action.

\section{Theoretical Implications/Conclusions}

According to research, entrepreneurship and strategic management can be seen as inseparable. Entrepreneurship is about discovering the possibilities of generating money. In order to succeed in the business world, businesses must be capable of being imaginative and innovative. Entrepreneurial perspectives are like a balcony without Romeo or Romeo without a balcony, says the author. If a writing pen is unable to perform its duties without a writing paper and vice versa, it is both entrepreneurial and strategic management. This coincides with the figurative use cited in Kraus \& Kauranen, 2009, by Venkataraman and Sarasvathy (2001). It is impossible for the two definitions to be viewed entirely separately from each other. In accordance with the theories of anthropology, this is (Simpeh, 2011; Baskerville, 2003). The undeniable fact that both entrepreneur and strategic planner are both interested in the business of thinking about how to find and exploit available opportunities was also brought to light in this report. It therefore holds the view that entrepreneurship and strategic leadership, whether new or existing ventures, are two inseparable entities driven by a deep desire to achieve the economic development and survival of an entity. No business venture will achieve the height it needs without an interplay of the two concepts that are seen and perceived as couples coming together to give birth (economic growth and wealth creation). 


\section{References}

Anderson, A., \& Miller, C. (2003). Class matters: human and social capital in the entrepreneurial process. The Journal of Socio-Economics, 32, 17-36.

Andrews, K.R. (1987). The concept of corporate strategy. Homewood: Irwin.

Bettis, R.A., \& Hitt, M.A. (1995). The new competitive landscape. Strategic Management Journal, 16(5), 7-16.

Brocks, W.A., \& Evans, D.S. (1989). Small business economics, 1(1), 7-20.

Baskerville, R.F. (2003). Hofstede never studied culture, accounting, organisations and society, 28(1), $1-14$.

Chandler, G., \& Hanks, S.S. (1998). An examination of the substitutability of founder's human and financial capital in emerging business venture. Journal of Business Venturing, 13, 353-369.

Clausen, T.H. (2006). Who identifies and exploits entrepreneurial opportunities. Retrieved from www.ccsr. ac.uk.

Carree, M.A., \& Thurik, A.R. (2000). The impact of entrepreneurship on economic growth. Handbook of Entrepreneurship, Boston Kluwer Academic Publisher.

Covin, J.G., \& Miles, M.P.(1999). Corporate entrepreneurship and the pursuit of competitive advantage. Entrepreneurial Theory \& Practice, 23(3), 46-47.

Drucker, P.F. (1985). Innovation and entrepreneurship. New York: Harper \& Row Publishers.

Furrer, O., Thomas, H., \& Goussevskaia, A. (2007). The structure and evolution of strategic the management field: a content analysis of 26 years of strategic Management research. International Journal of Management Reviews.

Hitt, M.A., Ireland, R., Camp, M., \& Sexton, D.(2002). Strategic entrepreneurship: integrating entrepreneurial and strategic management perspective. In M.A.Hitt, R. Ireland, M. Camp \& D. Sexton (Eds.), strategic entrepreneurship: creating a new mindset (1-14), Blackwell.

Hitt, M.A., Ireland, R.D., \& Hoskisson, R.E. (2001). Strategic management: competitiveness and globalization 4ed. Cincinatti: South-Western College Publishing.

Hurst, E., \&Lusardi, A. (2004). Liquidity constraints, household wealth, entrepreneurship. Journal of Political Economy, 2,112

Kraus, S. \& Kauranen, I. (2009). Strategic management and entrepreneurship: friends or foe? International Journal of Business Science and Applied Management, 4(1).

Kavousy, E., Shahhosseini, A., Kiasi, S., \& Ardahaey, F.T. (2010). Cultural entrepreneurship strategy in Iran. Serbian Journal of Management, 5(2),227-241.

Landstrom, H.(1998). The root of entrepreneurship research, conference proceedings, Lyon, France, November 26-27.

Lumpkin, G.T., Shrader, R.C., \& Hills, G.E. (1998). Does formal business planning enhance the performance of new ventures? Frontiers of Entrepreneurship Research, 180-199.

McGrath, R.G., \& MacMillan, I.C., \& Scheinberg, S.(1992). Elitists, risk-takers, and rugged individualists? An exploratory analysis of cultural differences Between entrepreneurs and non-entrepreneurs. Journal of Business venturing, 7, 115-135

Meyer, G.D., Neck, H.M., \& Meeks, M.D. (2002). The entrepreneurial strategic management interface. In M.A. Hitt, R.D. Ireland, S.M. Camp \& D.L. Sexton (Eds,), strategic entrepreneurship: creating a new mindset (19-44) Oxford: Blackwell.

Murphy, J.P., Liao, J. \& Welsch, P.H. (2006). A conceptual history of entrepreneurial thought. Journal of Management History, 12, 9-24.

McClelland, D.C. (1961). The achieving society, NJ: Van Nostrand, Princeton.

Naranjo-Valencia, D.J.J.V., Julia, C. (2011). Innovation or imitation? The role of Organization culture. Management Decision, 55-72. 
Ologbo, A.C., Oluwatoyin, O.S., \& Kwakye, E.O. (2012). Strategic management theories and the linkage with firm competitive advantage from the human resource-based view. International Journal of Research in Management \& technology, 2(4).

Porter, M.E. (1985). Comparative advantage: creating and sustaining superior performance. New York. The Free Press.

Prahalad, C.K., \& Hamel, G. (1990). The core competence of the corporation. Harvard Business Review, 68(3), 79-91.

Reynolds, P.D. (1991). Sociology and entrepreneurship: Concepts and contributions. Enpreneurship Theory \& Practice, 16(2), 47-70.

Rotter, J. (1966). General expectancies for internal versus external control reinforcement. Psychological Monographs, Whole No 609.

Schumpeter, J.A. (1934). The theory of economic development. New Branswick, London: Transaction Publishers.

Shane, S., \& Venkataraman, S. (2000). The promise of entrepreneurship as a field of research. Academy of Management Review, 25(1), 217-226.

Shane, S.A (1994). The effect of national culture on the choice between licensing and direct foreign Investment. Strategic Management Journal 15,627-642.

Shane, S.A \&Eckhardt, J.T. (2003). Opportunities and entrepreneurship. Journal of Management, 29 (3), 333-349.

Stevenson, H.H., \& Jarillo, J.C. (1990). A paradigm of entrepreneurship: entrepreneurial Management. Strategic Management Journal, 11(4), 17-27.

Simpeh, K.N. (2011). Entrepreneurship theories and empirical research: A summary review of the literature. European Journal of Business and Management, 3(6).

Venkataraman, S. \& Sarasvathy, S. D. (2001). Strategy and entrepreneurship. Outline of an untold story. In M.A. Hitt, E. Freeman \& J.S. Harrison (Eds.). Handbook of Strategic management (650-668). Oxford: Blackwell.

Yarbrough, N.A.L. (2011). The impact of product market strategy- organizational culture fit on business performance. Journal of the Academy of Marketing Science, 555-573. 